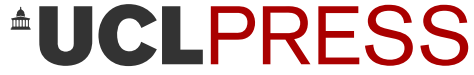

\section{The Journal of the Sylvia Townsend Warner Society}

\section{Guests of Spain}

Valentine Ackland*

How to cite: Ackland, V. 'Guests of Spain.' The Journal of the Sylvia Townsend Warner Society, 2020, 19(1-2), pp. 19-21・DOI: https://doi.org/10.14324/ 111.444. stw.2020.05

Published: 15 April 2020

\section{Copyright:}

(C) 2020, Tanya Stobbs. This is an Open Access article distributed under the terms of the Creative Commons Attribution License (CC-BY) 4.0 https://creativecommons.org/licenses/by/4.0/, which permits unrestricted use, distribution and reproduction in any medium, provided the original author and source are credited • DOI: https://doi.org/10.14324/111.444.stw.2020.05

This is a reprint originally published in Daily Worker (17 July 1937).

\section{Open Access:}

The Journal of the Sylvia Townsend Warner Society is a peer-reviewed open access journal. 


\title{
Guests of Spain
}

\author{
Valentine Ackland
}

\section{Abstract}

A short story by Valentine Ackland published in Housewife magazine in December 1950.

Keywords Valentine Ackland; ghost story.

The Second Congress of the International Association of Writers in Defence of Culture: Madrid, 1937

There has never been a Congress like this before. More than sixty delegates from all countries met together in Madrid - in the front line held by the fighters for freedom and for intellectual liberty.

Gathered there, as honoured guests of the Republican Government of Spain, we discussed the present phase of the world war from our national points of view and unanimously agreed that we must combat Fascism everywhere as Intellectual Enemy Number One.

In Madrid, under artillery fire and air-raids, with the incessant noise of battle and the inexpressible excitement of renewed Government attack and success, we heard speeches from the leading writers of all countries: from philosophers and Catholics like Bergamin, sociologists like Max Hodann, exiles like Kisch and Anna Seghers, novelists like Sylvia Townsend Warner, poets like Octavio Paz and Stephen Spender and the writers in uniform like Ludwig Renn, Jef Last and Andre Malraux. On a platform which they shared with the guard of honour of soldiers in fighting kit and with Trades-Union and Youth Delegates, these representatives of world culture discussed the 
immediate problems of literature in the fight against fascism and for the liberty of peoples.

As guests of the Spanish Government we were treated with such splendid hospitality and honour that those of us who return to live under a 'Civilised Democracy' feel indeed exiled from civilisation. Among a hundred happenings here are two which point the contrast most sharply:

Going by car from Valencia to Madrid we stopped for lunch at a small village. During the fine meal spread for us we heard a crowd of children gathering outside the hall. They started to sing, and sang us the war songs of Spain, 'Riego's Hymn' and then the International. After exchanging shouted greetings with them, when we embarked again for our journey we found their mothers waiting to greet us with handshakes, embraces, tears. These women told us they were refugees from Badajoz and Madrid, from sacked villages and towns. 'My husband was shot in the massacre at Badajoz -' 'I am alone here, with my child. We have no one left - Viva la Republica! Viva los Intellectuales!' They thanked us for coming to Spain. They charged us to write about Spain, for Spain, when we returned home. Always they ended with 'Viva los Intellectuales!'

We had experienced our first air-raid in Valencia; we went on to land and air bombardment in Madrid, but this was our real experience of this war. And for the rest of the journey, on all the various tours we made, we were to hear everywhere that extraordinary, that unbelievable greeting from even the smallest village, the most isolated group of peasants: 'Viva los Intellectuales!' To the English delegation at least it was scarcely credible, and at dinner that night in Madrid the Cuban and Dutch delegates treated us to some gently ironical remarks about the contrast between the 'ignorant Spanish peasants' and our own Harrow-and-Oxford, Eton-and-Cambridge Foreign Office, which can only recognise 'bona fide business reasons' as validating travel to Spain!

Casals, who conducted a concert in our honour at Barcelona, asked the leader of our Delegation whether we could not now return to England satisfied that Republican Spain was not a country of barbarians? It was a serious question but if it had been a gibe it would have been amply justified.

The second happening was personal to the members of the English delegation but perfectly typical of the spirit of Republican Spain. Returning to Valencia we went to a very small hotel, a place where peasants of the neighbouring villages stay when they go to town. As we were unpacking there came a knock on the door and the 
proprietor entered with an interpreter, asking to speak to the leader of our Delegation. He made a speech of welcome, saying that he was immensely proud of being allowed to shelter and entertain delegates to the Writers' Congress, that he thanked us for coming, that he begged us to have all we wanted while we were there. He had had no notice of our coming and Valencia is overcrowded, but on the next afternoon he gave us a banquet of the best Valencian food, on a table wreathed with roses and sweet-smelling flowers, and that evening, although he lives outside the city, he stayed on with the waiters to look after us, despite the fact that the session of Congress lasted far beyond the usual hours and it was a Saturday - the night, he told us, when Valencia anticipates bombardment.

We enjoyed magnificent hospitality from the Government wherever we went in Spain; concerts, receptions and motor tours were given us whenever the business of the Congress allowed us the time to go. But these two incidents typify the attitude of the working masses of Spain to the intellectual workers of all countries and surely prove conclusively where is the real future of culture and, by sharp and undeniable contrast, where is barbarism and gross intellectual darkness.

Daily Worker (17 July 1937) ${ }^{1}$

\section{Note}

1 The text above is taken from Ackland's

STW.2012.125.2691. Ackland has three-page typescript in the Sylvia Townsend Warner and Valentine Ackland archive; Dorset History Centre item 